\title{
MONITORING AMPHIBIAN POPULATIONS IN Yellowstone aNd Grand Teton National Parks
}

\author{
Charles R. PETERSON $\downarrow$ DeParTMENT OF BIological SCIENCES \\ IDAHO STATE UNIVERSITY • IDAHO MUSEUM OF NATURAL HISTORY \\ POCATELLO
}

\author{
EDWARD D. KOCH \\ U. S. FISH AND WILDLIFE SERVICE \\ BOISE
}

\author{
PAUL STEPHEN CORN \\ U. S. FISH AND WILDLIFE SERVICE \\ NATIONAL ECOLOGY RESEARCH CENTER \\ FORT COLLINS
}

\section{$-\quad$ INTRODUCTION}

Many amphibian populations appear to be declining throughout much of the world (Corn and Fogleman 1984, Beiswenger 1986, McAllister and Leonard 1990, Wake and Morowitz 1990, Wake 1991). Declines appear to be particularly noticeable in the western United States in the true frogs and toads (families Ranidae and Bufonidae, respectively). For example, leopard frogs (Rana pipiens) and western toads (Bufo boreas) have disappeared from the majority of their historic ranges in Colorado (Corn et al. 1989) and populations of spotted frogs (Rana pretiosa) have gone extinct or declined on the periphery of their range in Washington, Oregon, California, Nevada, and Utah (McAllister and Leonard 1990).

Monitoring amphibian populations is important for several reasons. First and most obvious, we need to know if and why amphibian populations are fluctuating so we can effectively manage and preserve them. Second, amphibians are important components of many ecosystems, both as predators and prey, often making up a significant amount of a system's biomass (Pough 1983). Finally, amphibians are potentially sensitive indicators of environmental change because of a unique combination of biological characteristics such as their permeable skins, biphasic life cycles, and aquatic reproduction and development (Wake and Morowitz 1990). For these reasons, the monitoring of amphibians populations has been recommended as an "early warning system" of environmental change (Beiswenger 1986, 1988, Wake 1991).

Two major questions need to be addressed to understand declines in amphibian populations:

(1) To what extent are amphibian populations actually declining? The evidence for declining populations is largely anecdotal and there are few quantitative, long-term studies of amphibians populations (Wake 1991). We do not know what percentage of species are affected or to what extent their populations have declined. Consequently, to determine how widespread this problem is, top research priorities should include resurveying previously studied populations and initiating integrated, long-term studies of populations (Wake and Morowitz 1990, Pechmann et al. 1991).

(2) If populations are decreasing, what are the causes of the declines? A variety of factors may be involved with declines in amphibian populations, including temperature changes, increased ultraviolet 
radiation, air and water pollution, drought, habitat destruction, and the introduction of exotic species. The causes of declines which have occurred in relatively undisturbed areas such as national parks and wilderness areas are of special concern and interest. A key issue is the extent to which population fluctuations are the result of natural causes, such as drought, versus anthropogenic causes, such as pollution (Pechmann et al. 1991). Because of this diversity of potential factors, we need data for a variety of species and locations to understand the extent of this problem and to determine its causes (Wyman 1990). We need to gather data on environmental variation and the responses of individual amphibians to that variation as well as documentation of population fluctuations.

The Greater Yellowstone Ecosystem (Anderson 1991, Marston and Anderson 1991) is an important location for a amphibian monitoring program for several reasons (Koch and Peterson 1989), including: (1) it is located in the northern intermountain west, an area for which there is relatively little information; (2) it is relatively undisturbed and thus may provide comparisons valuable for testing hypotheses concerning the causes of declines in amphibian populations (e.g., water pollution); (3) it is relatively protected and will be available for long term studies; (4) there are historical distribution data for the five amphibian species occurring there, including population data for spotted frogs (Rana pretiosa) (Turner 1958, 1960) and for tiger salamanders (Ambystoma tigrinum) (Fishery and Aquatic Management Program in Yellowstone National Park Technical Reports for Calendar Years 1964-1982); and (5) the amphibian species which occur there are experiencing problems elsewhere in their ranges (Corn and Fogleman 1984, Harte and Hoffman 1989, McAllister and Leonard 1990). The Greater Yellowstone Ecosystem will therefore be an important site when an international network of monitoring sites for amphibian populations is established.

\section{OBJECTIVE OF CURRENT STUDY}

The objective of this study was to initiate a monitoring program to help determine the status and trends of amphibian populations in Yellowstone and Grand Teton National Parks.

\section{- METHODS}

We monitored amphibian populations at eight sites (Figure 1). Six sites were located in Yellowstone National Park (Slide Lake, Slough Creek Road Pond, Harlequin Lake, Lodge Creek, Indian Pond, and South Entrance Pond) and two sites were located in the Jackson Hole area (Lower Moose Pond and Togwotee Pass Pond). These sites were chosen on the basis of location, elevation, accessibility, the existence of previous data, and the present occurrence of amphibians.

Our principal sampling technique consisted of timed searches along the shores of lakes and ponds and along the banks of streams. We counted the number of egg masses found and all the individuals seen and classified them as adults, juveniles, recently transformed (metamorphs), or larvae. In the case of large numbers of larvae or metamorphs, we only estimated their numbers. Dip nets were used to collect larvae and tadpoles for identification. We listened for calls of chorus frogs (Pseudacris triseriata) during the spring sampling. We also experimented with the use of minnow traps at Harlequin Lake and Lower Moose Pond to sample for larvae and tadpoles.

During the first visit, we described the site using a standard format developed by U.S. Fish and Wildlife Service (USFWS) personnel (date, location, area, depth, origin, type, substrate, vegetation, etc.). We noted beginning and ending times and the number of observers so that observation rates for each species could be calculated. Water samples were taken at each site during the first two sampling periods and shipped to Fort Collins, Colorado for analysis $(\mathrm{pH}$, conductivity, and ions) by the U.S. Forest Service (USFS). We also recorded shaded $1 \mathrm{~m}$ air temperatures and $1 \mathrm{~cm}$ water temperatures at one or more locations. Cloud cover, relative wind speed, and general weather conditions were also noted for each sampling period. We sampled each site once per month from May through August. Park personnel also sampled most of these sites several times during June and August.

To detect long-term changes in populations, we attempted to make comparisons with sites that had been studied in the early 1950's by Frederick B. Turner $(1955,1960)$ in Yellowstone National Park 


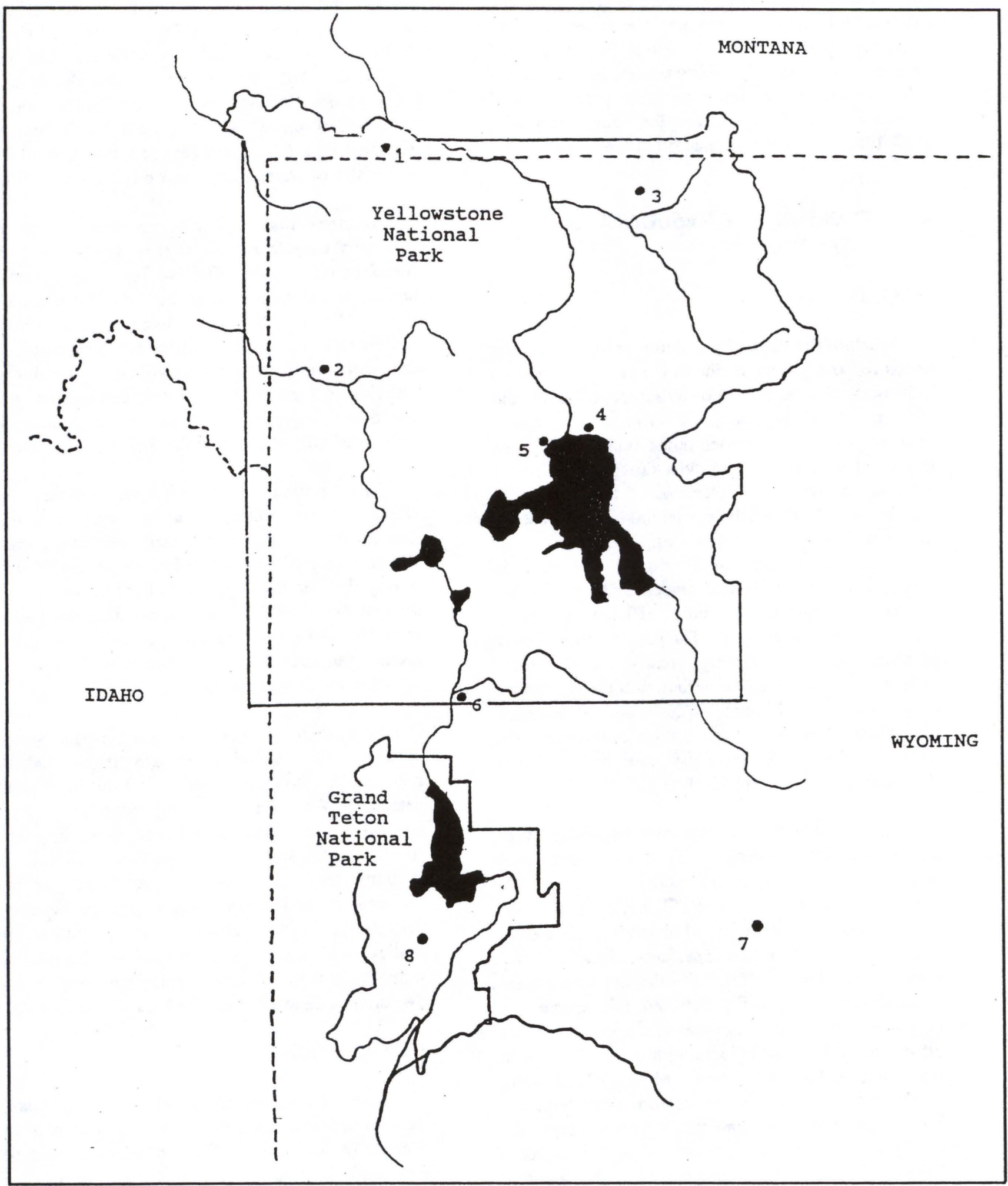

Figure 1. Location of amphibian sampling sites in the Greater Yellowstone Ecosystem; (1) Slide Lake; (2) Slough Creek Road Pond; (3) Harlequin Lake; (4) Indian Pond; (5) Lodge Creek; (6) South Entrance Pond; (7) Togwotee Pass Pond; (8) Lower Moose Pond. 
and Charles C. Carpenter $(1953 \mathrm{~b}, 1954)$ in the Jackson Hole area. Turner and Carpenter revisited their study sites with us from 20-21 June and 24-27 June 1991, respectively. Between July and August of 1991, we also conducted a mark/recapture study of spotted frogs at Lodge Creek for comparison with 1953-1955 population estimates (Turner 1960).

\section{- Preliminary Results AND DISCUSSION}

\section{SAMPLING}

Much of the difficulty in determining population trends for amphibians is due to the variety of factors influencing their activity and abundance, including the species, life stage, sampling technique, weather, time, and location. We often failed to observe a given species at a particular. site even though we found it there at another time. Because of the number of variables involved and their potential interactions, we feel that careful sampling using a variety of techniques at several times during the year is required. Once a general understanding of these effects is achieved, a more efficient sampling schedule can be developed. The participation of park personnel in the sampling greatly increased our understanding of temporal variation in the abundance of amphibians. Although we have not yet analyzed the effects of weather variation on our results, the spring of 1991 was generally cool and wet and presumably delayed reproductive activity.

Tiger salamanders (Ambystoma tigrinum) were relatively difficult to sample. They were most easily seen in the water, either as adults or larvae. We found eggs only at one site (Slide Lake). It was apparent that the probability of observing this species was more affected by the experience of the observer than for the other species. We did not locate them consistently and typically detected this species on only one or two sampling dates at a given site. Our efforts to collect individuals with minnow traps at Harlequin Lake and Lower Moose Pond were unsuccessful but, given the success that Carpenter (1953a) had with this technique, we plan to try again next year, earlier in the season. Tiger salamanders have been found in pit traps placed out for sampling small mammal populations (Mary Harter, pers. comm.) but we did not use traps because of our limited sampling schedule and because many of the sites are visible to the public. Previous lake surveys for fish indicate that gill netting is effective (Fishery and Aquatic Management Program in Yellowstone National Park - Technical Reports for Calendar Years 1964-1982) but often results in the death of the salamanders. Although mass migrations of salamanders have been reported in Yellowstone National Park (Koch and Peterson 1989), we did not encounter or hear of any such migrations in 1991.

Western toads (Bufo boreas) are apparently relatively easy to sample if they are present. The timed searches were effective for sampling adults, larvae, and metamorphs at the South Entrance Pond site. We did not hear them calling although individuals sometimes vocalized when captured. We did not find any eggs. Many transforming individuals were seen from June through August at the South Entrance Pond site in a geothermally influenced side-channel of the Snake River.

The presence of Western chorus frogs (Pseudacris triseriata) at a site was most easily determined by listening for their calls in the spring. We encountered adults at a low rate (only 27 adults during the study). Eggs were hard to find and only seen at two sites. We saw fewer tadpoles than we expected to find on the basis of calling and adults seen. Tadpoles were only observed at one of the sites (South Entrance Pond).

Spotted frogs were the most easily sampled species. We found all stages (eggs, tadpoles, metamorphs, juveniles, and adults) during the timed searches. We did not hear any calling. Eggs were found from mid May to mid June, depending on the location of the site. We captured many tadpoles in a minnow trap in Lower Moose Pond but were unsuccessful at Harlequin Lake, perhaps because of differences in the substrates, sizes of the water bodies, and times of development. Transforming individuals were observed from late July to early September, depending on the location of the site.

\section{DISTRIBUTION}

Table 1 summarizes which species and stages were observed at each of the sites as well as historic records of occurence. Tiger salamanders had been previously recorded at or near five of our eight sampling sites. We found salamanders at four of the five sites where they had previously been found. We may have failed to detect the presence of this species at some sites because of sampling difficulties. 
Table 1. Amphibian species and life stage occurrence at eight sampling sites in Yellowstone and Grand Teton National Parks during 1991. An asterisk indicates that a species was recorded at or near that site before 1991. $\mathrm{A}=$ adult. $\mathrm{C}=$ calling. $\mathrm{E}=$ eggs. $\mathrm{J}=$ juvenile. $\mathrm{L}=$ larva or tadpole. $\mathrm{M}=$ recently metamorphosed individual.

$\begin{array}{llllll} & \text { Days } & \text { Tiger Salamander } & \text { Western Toad } & \text { Western Chorus Frog } & \text { Spotted Frog } \\ \text { Sampling Site } & \text { Sampled } & \text { Ambystoma tigrinum } & \text { Bufo boreas } & \text { Pseudacris triseriata } & \text { Rana pretioss }\end{array}$

\begin{tabular}{lccccc}
\hline Slide Lake & 7 & $*$ E L & & A C & A E J M \\
Harlequin Lake & 11 & $*$ L & $*$ & A C & AE JLM \\
$\begin{array}{l}\text { Slough Creek Road } \\
\text { Pond }\end{array}$ & 7 & $*$ A J L & $*$ & A C & * A E J \\
$\begin{array}{l}\text { Indian Pond } \\
\text { Lodge Creek (upper) }\end{array}$ & 13 & $*$ & J L & $*$ & AE JLM \\
South Entrance Pond & 10 & $*$ J & $*$ A & * A E J L M \\
Togwotee Pass Pond & 3 & $*$ A L & A L M & A C L & A E L \\
Lower Moose Pond & 7 & $*$ & C & $*$ A L M \\
\hline
\end{tabular}

Western toads were found at only three of the eight sites and at only one of five sites for which previousrecords are available. Carpenter (1953b) described western toads as the most wide-spread amphibian in the Jackson Hole region. We do not believe the apparent limited distribution is the result of ineffective sampling. Because western chorus frogs were found at seven of the eight sites, we considered them to be widespread as did Turner (1955). They may also occur at the Indian Pond site but may simply have not been detected. Spotted frogs were found at all eight sampling sites and, thus, were the most wide-spread species.

\section{ABUNDANCE}

Because of the variety of factors influencing the visibility of amphibians, it is difficult to estimate abundances from the timed search data. Based on the number of adults observed, spotted frogs were the most abundant species (over 750 adults observed), followed by tiger salamanders ( 49 adults), western chorus frogs ( 27 adults), and western toads (10 adults). The calling activity of the chorus frogs suggests that they actually may be more abundant than the tiger salamanders. Adult western toads were only observed at one site (South Entrance Pond). Tadpoles and metamorphs were very abundant there, numbering in the thousands. Hundreds of toad tadpoles were also observed at Indian Pond. Based on conversations with Charles Carpenter and on the 1991 field data, western toad populations appear to have declined since the 1950's. Based on the water samples we collected in 1991, acidity does not appear to be a problem for amphibians in the Greater Yellowstone Ecosystem (Corn and Vertucci, in press.).

Although spotted frogs appeared to be abundantand reproducing at all locations sampled, we do not know what the population trends are. Seasonal variation in the number and observation rates of spotted frogs was great (Figure 2). Turner's subjective impression from his 1991 visit was that 
44

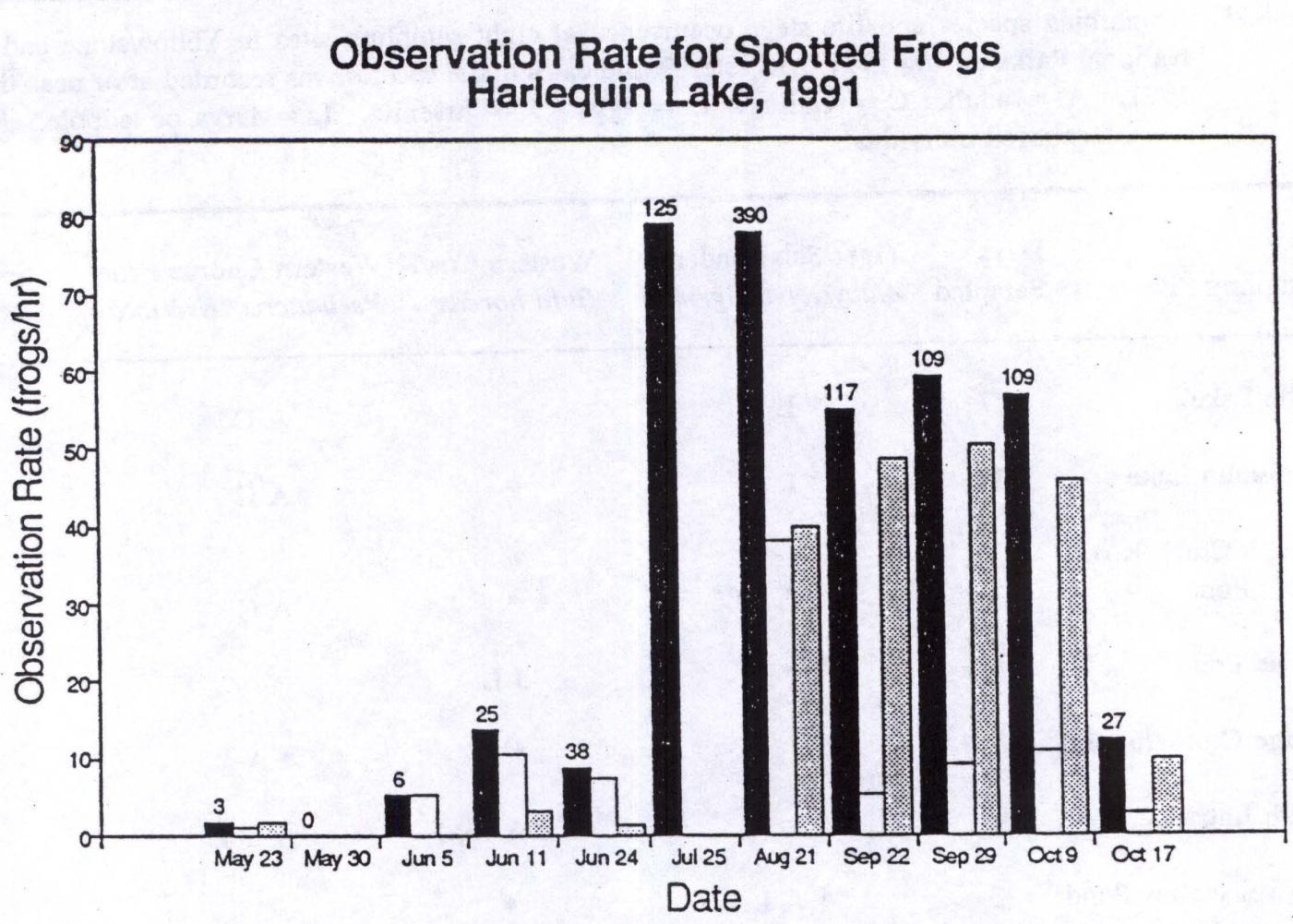

Figure 2. Observation rates of spotted frogs (Rana pretiosa) at Harlequin Lake during 1991. The juvenile category includes recently transformed individuals. The numbers above the bars indicate the total number of individuals observed on that day.

there were fewer spotted frogs now than in the 1950 's. We found very few spotted frogs during two visits to the Natural Bridge Area in Yellowstone National Park, even though Turner had observed that they were abundant there in the 1950's. Our preliminary analysis of $1991 \mathrm{mark} /$ recapture data for spotted frogs at Lodge Creek suggests that, although many frogs are still present, a dramatic decline (about 60-80\%) has occurred since the 1950's. On 16-17 July 1991 we captured, marked (freeze-branded), and released 104 spotted frogs in the upper portion of Lodge Creek. On August 24, we captured 87 frogs, 37 of which had been marked. This recapture ratio indicates a population size of about 245 , compared to Turner's population estimates of 1000-1600 frogs in 1953-1955 (Turner 1960). Unfortunately, this site has been heavily disturbed by roads and a water well system and thus is probably not representative of the Park as a whole. The construction of roads and buildings in Grand Teton National Park also prevented comparisons of current and past abundances at Carpenter's best studied sites (Carpenter 1954).

\section{- SUMMARY}

1. Western toads were easy to sample, had a limited, possibly decreasing distribution with relatively few adults observed, and successfully reproduced at two of the sites. This species appears to be less widespread and less abundant 
than in the past, especially in the southern portion of the Greater Yellowstone Ecosystem.

2. Spotted frogs were easy to sample, widespread, abundant, and reproducing successfully.

3. The widespread distribution of western chorus frogs was easy to determine because of their spring calling behavior. However, relatively few adults, eggs, or tadpoles were observed.

4. Tiger salamanders were moderately difficult to sample and were only found at half of the sites. We encountered a moderate number of individuals.

5. It is difficult to determine population trends because of a lack of previous studies. Unfortunately, those sites for which previous population data were available had been modified by developments so that meaningful comparisons could not be made. We recommend that the parks identify previous study areas and try to protect such sites from further development.

\section{- ACKNOWLEDGEMENTS}

Many organizations and people helped with this study. Direct funding for travel expenses and materials was supplied by the University of Wyoming - National Park Service Research Center. The US Fish and Wildlife Service (Fort Collins, CO) covered the cost of analyzing the water samples and the time and travel expenses for Stephen Corn, Ted Koch, Mike Jennings, and Joe Kiesecker. The USFWS (Boise, ID) made it possible for Ted Koch to particpate in this project. Chuck Peterson's time was covered in part by the Idaho Museum of Natural History. John Varley, Stewart Coleman, and Pete Hayden generally encouraged pursuit of this study, helped with permits, and arranged for park personnel to assist with sampling. Roger Andrascik, Denise Culver, Nancy Kehoe, Kristin Legg, Craig McClure, Tom Oliff, and Jim Sweaney enthusiastically assisted with the sampling and virtually doubled the amount of information we were able to obtain. Mike Jennings and Joe Kiesecker of the USFWS (Fort Collins, CO) also provided key assistance with sampling. Dan Carty and Lynn Kaeding (USFWS) helped with arranging accommodations and greatly facilitated our work in Yellowstone National Park. Glenn Plumb arranged for accommodations at the
UW-NPS research station. Eric Stone (Teton Science School) provided amphibian distribution information for the Jackson Hole area. Christine Britton (Idaho State University) assisted with collecting and analyzing the mark-recapture data at Lodge Creek. Fred Turner and Chuck Carpenter spent several days with us revisiting their study sites from the 1950's and provided an invaluable perspective on amphibian populations in the Greater Yellowstone Ecosystem. Finally, we would like to thank the many other people who provided us with information concerning amphibians in this region.

\section{- Literature Cited}

Anderson, J.E. 1991. A conceptual framework for evaluating and quantifying naturalness. Conservation Biology 5:347-352.

Beiswenger, R.E. 1986. An endangered species, the Wyoming Toad Bufo hemiophrys baxteri - the importance of an early warning system. Biol. Conserv. 37:59-71.

Beiswenger, R.E. 1988. Integrating anuran amphibian species into environmental assessment programs. In: Management of Amphibians, Reptiles, and Small Mammals in North America. USDA Forest Service General Technical Report RM-166.

Carpenter, C.C. 1953a. Trapping technique for aquatic salamanders. Herpetologica 8:183

Carpenter, C.C. 1953b. An ecological survey of the herpetofauna of the Grand Teton-Jackson Hole area of Wyoming. Copeia 1953:170-174.

Carpenter, C.C. 1954. A study of amphibian movement in Jackson Hole Wildlife Park. Copeia 1954:197-200.

Corn, P.S. and J.C. Fogleman. 1984. Extinction of montane populations of the Northern Leopard Frog (Rana pipiens) in Colorado. J. of Herpetology 18:147-152.

Corn, P.S. and F.A. Vertucci. In press. Descriptive risk assessment of the effects of acidic deposition on Rocky Mountain Amphibians. J. of Herpetology. 
Corn, P.S., W. Stolzenburg, and R.B. Bury. 1989. Acid precipitation studies in Colorado and Wyoming: interim report of surveys of montane amphibians and water chemistry. Biological Report 80 (40.26). Air Pollution and Acid Rain Report No. 26.

Harte, J. and E. Hoffman. 1989. Possible effects of acidic deposition of a Rocky Mountain population of the tiger salamander Ambystoma tigrinum. Conserv. Biol. 3:149-158.

Koch, E.D. and C.R. Peterson. 1989. A preliminary survey of the distribution of amphibians and reptiles of Yellowstone National Park. In: Rare, sensitive and threatened species of the Greater Yellowstone Ecosystem, T.W. Clark, D.H. Harvey, R.D. Dorn, D.C. Genter, and C. Groves (eds.), Northern Rockies Conservation Cooperative, Montana Natural Heritage Program, The Nature Conservancy, and Mountain West Environmental Services.

Marston, R.A., and J.E. Anderson. 1991. Watersheds and vegetation of the Greater Yellowstone Ecosystem. Conserv. Biol. 5:338346.

McAllister, K.R. and B. Leonard. 1990. 1989 Progress Report - Past distribution and current status of the spotted frog in western Washington. Washington Department of Wildlife, Wildlife Management, Nongame Program.
Pechmann, J.K.H., D.E. Scott, R.D. Semlitsch, J.P. Caldwell, L.J. Vitt, and J.W. Gibbons. 1991. Declining amphibian populations: the problem of separating human impacts from natural fluctuations. Science 253: 892-895.

Pough, F.H. 1983. Amphibians and reptiles as lowenergy systems. Pages 141-188 In: W.P. Asprey and S.I. Lustick, editors. Behavioral energetics. Ohio State Univ. Press, Columbus.

Turner, F.B. 1955. Reptiles and amphibians of Yellowstone National Park. Yellowstone Interpretive series No. 5. Yellowstone Library and Museum Association, Mammoth, Wyoming.

Turner, F.B. 1958. Life history of the western spotted frog in Yellowstone National Park. Herpetologica 14:96-100.

Turner, F.B. 1960. Population structure and dynamics of the western spotted frog, Rana $p$. pretiosa Baird \& Girard, in Yellowstone Park, Wyoming. Ecol. Monogr. 30:251-278.

Wake, D.B. 1991. Declining amphibian populations. Science 253: 860.

Wake, D.B. and H. Morowitz. 1990. Declining Amphibian Populations - A Global Phenomena? Workshop sponsored by Board on Biology, National Research Council. Irvine, CA.

Wyman, R.L. 1990. What's happening to the amphibians? Conserv. Biol. 4:350-352. 


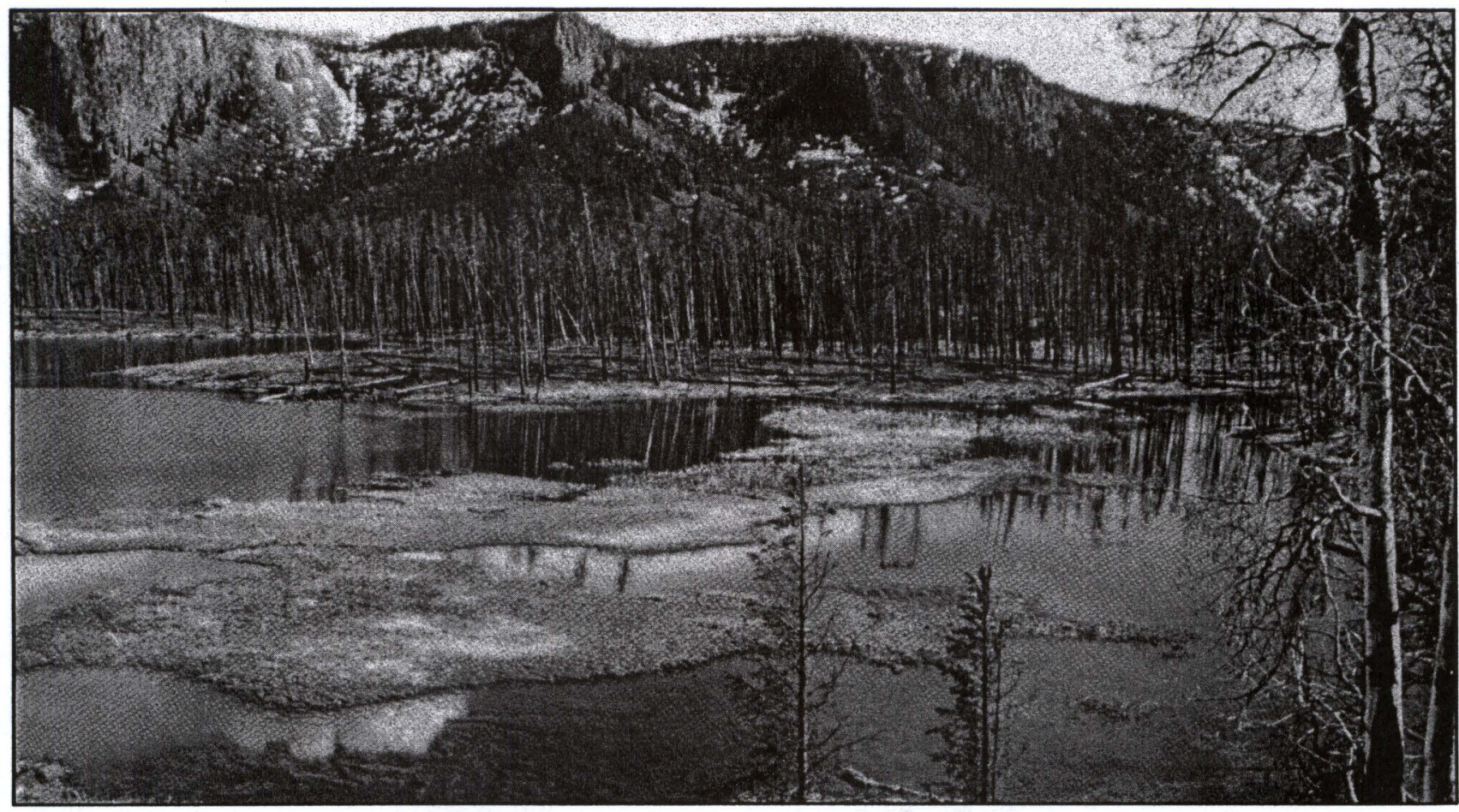

\section{Harlequin Lake.}

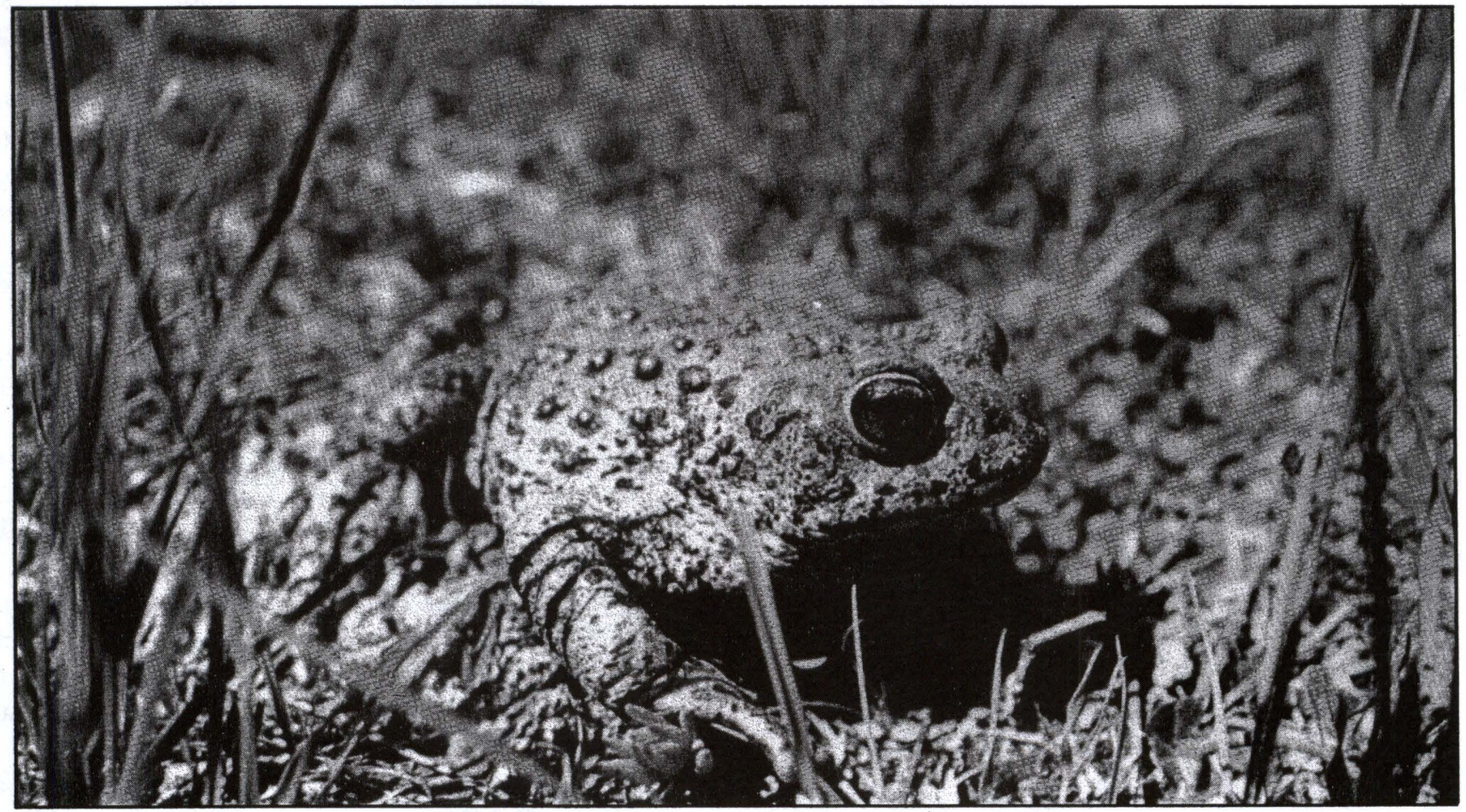

2. Western toad (Bufo boreas). 